\title{
Water chemistry and not urbanization influences community structure of non-marine Ostracoda (Crustacea) in northern Belgium
}

\author{
Marie Cours $^{1 \oplus}$, Jan Vanaverbeke ${ }^{1 \oplus}$, Koen Parmentier ${ }^{1 \oplus}$, Marc Knockaert ${ }^{1 \oplus}$, \\ Janet Higuti ${ }^{2}$, Koen Martens ${ }^{1,3, *, \# ~} \odot$ \& Isa Schön ${ }^{1,4, \#} \odot$ \\ ${ }^{1}$ Royal Belgian Institute of Natural Sciences, Natural Environments, Vautierstraat 29, \\ 1000 Brussels, Belgium. \\ ${ }^{2}$ State University of Maringá (UEM), Centre of Research in Limnology, Ichthyology and Aquaculture \\ (Nupélia), Graduate Programme in Ecology of Inland Water Ecosystems (PEA), Av. Colombo, \\ 5790, CEP 87020-900. Maringá, PR, Brazil. \\ ${ }^{3}$ Ghent University, Biology, K.L. Ledeganckstraat 35, 9000 Ghent, Belgium. \\ ${ }^{4}$ University of Hasselt, Researchgroup CMK, Diepenbeek, Belgium. \\ *Corresponding author: kmartens@naturalsciences.be \\ \#joint senior authors
}

\begin{abstract}
Urbanization is one of the major causes of the destruction of natural habitats in the world. Cities are urban heat islands and can thus significantly influence populations of plants and animals. The research project SPEEDY investigated the effects of urbanization in northern Belgium with a nested sampling design at local and landscape scales for a variety of organisms. Here, we tested the effects of urbanization on non-marine ostracod communities, sampling 81 small pools in three urbanization categories, as defined by percentage built up cover (low, intermediate, high). We identified 17 ostracod species, together occurring in 60 of the 81 sampled pools. We found that urbanization per se had no significant effect on ostracod communities. Of all the measured local factors, ammonium and total phosphorus concentrations had a significant effect on the community structure. In contrast, water temperature had no significant effect, most likely because the ostracod species found in northern Belgium in the present survey mostly have wide temperature tolerances.
\end{abstract}

Keywords. Freshwater ecology, anthropogenic impact, nutrients, ammonium, phosphorus, built-up cover.

Cours M., Vanaverbeke J., Parmentier K., Knockaert M., Higuti J., Martens K. \& SchÖn I. (2021). Water chemistry and not urbanization influences community structure of non-marine Ostracoda (Crustacea) in northern Belgium. Belgian Journal of Zoology 151: 149-167. https://doi.org/10.26496/bjz.2021.91

\section{Introduction}

Man has influenced natural environments for thousands of years. During the last centuries and decades, urbanization has become one of the major drivers of evolution and adaptation for natural animal and 
plant populations (LAMBERT \& DONIHUE 2020). Urbanization is also the second largest cause of habitat destruction world-wide (ELLIS et al. 2010). It does not only lead to reduced species richness (MCKINNEY 2008) and diversity (SHOCHAT et al. 2006; BRADLEY \& AltiZer 2007), but cities are in fact also selective agents (ALBERTI 2015), causing significant micro-evolutionary changes and adaptations over sometimes very short time frames (BRANS et al. 2017). Animal and plant populations in urbanized areas have shown a broad range of adaptive responses concerning behaviour, morphology and physiology (reviewed by Alberti 2015 and Donihue \& LAMBert 2015). Alberti et al. (2017) found a clear signal of increasing phenotypic change through urbanization in a large meta-analysis of more than 1600 phenotypic trait changes from different animals and plants. Urbanization can furthermore disturb natural ecosystems through a variety of factors, such as holding higher temperatures than surrounding nonurbanized areas (hence the term urban heat islands - OKE 1982), changing social and biotic interactions, climate change, light and noise pollution, food availability, habitat heterogeneity in space and time, and novel disturbances such as floods, fires, stressors, pollutants or ecotoxins (TÜZÜN et al. 2015; ALBERTI et al. 2017). The importance of urbanization as an evolutionary driver is expected to further increase over the next decades, given that more than two-thirds of the global human population will live in cities within the next 30 years (UNITED NATIONS 2018) and that the effects of urbanization extend far beyond city boundaries (BRADLEY \& ALTIZER 2007). Thus, investigating the effect of urbanization on different ecosystems and animal and plant species is essential to understand the role of humans in eco-evolutionary dynamics of ecosystems and communities, and to develop sustainable management strategies for cities (LAMBERT \& DONIHUE 2020) and their natural populations in an increasingly urbanized world.

Freshwater habitats show high levels of biodiversity in relation to their surface area (DUDGEON et al. 2006). Covering less than $1 \%$ of the Earth's surface, freshwater habitats hold $10 \%$ of all known species, a situation which is known as the "paradox of freshwater". More in particular, small aquatic landscape elements such as pools contribute more to regional biodiversity, relative to their cumulative surface, than larger aquatic habitats such as rivers and lakes with comparable surfaces (DAVIES et al. 2008). In Europe, $25 \%$ of all aquatic species diversity depends on pools (DAVIES et al. 2008), but pools remain understudied freshwater habitats (CÉRÉGHINO et al. 2008; BOIX et al. 2012). At the same time, "urbanization is one of the greatest threats to freshwater biodiversity" (HILl et al. 2015) because small aquatic habitats like pools are especially vulnerable to anthropogenic pressures (BIGGS et al. 2005), including pollution, drainage and urban development, and receive less legislative protection (THORNHILL et al. 2017). Factors influencing aquatic biodiversity generally operate at both local and landscape spatial scales (ALLAN 2004) and this further increases the potential influence of urbanization on aquatic biodiversity. The large variety of urban pools, ranging from small garden pools to larger water bodies in parks (NIELSEN et al. 2014) translates into heterogeneous environmental conditions (HILL et al. 2015) and a large variation in size and complexity (HILL et al. 2017). Therefore, urbanization has potentially stronger effects on aquatic than on terrestrial animal and plant communities. Several recent overviews provide guidelines for promoting biodiversity in urban pools (OERTLI \& PARRIS 2019).

Most published studies on the effects of urbanization, however, have focused on terrestrial systems (MCKINNEY 2008; MEINEKE et al. 2013), especially birds and mammals. In addition, studies on the effects of urbanization on aquatic systems mostly investigate large riverine systems (CALDERON et al. 2014) or special small habitats such as tanks in bromeliads (TALAGA et al. 2017). In addition, the limited number of studies on urbanized pools mostly focused on a single urbanized area or city (JEANMOUGIN et al. 2014; Hill et al. 2015; NOBLE \& HASSALl 2015; Heino et al. 2017; TAlagA et al. 2017). Only a few studies have comparatively investigated pools from urbanized and non-urbanized areas (HASSALL 2014; Hassall \& ANDerson 2015; Hill et al. 2017; Perron \& PicK 2020a, 2020b) or along an urbanization (BRANS et al. 2017) or land use (THORNHILL et al. 2017) gradient. 
The effects of urbanization on biodiversity seem, to some extent, to be taxon specific, as some species appear to be more resilient to the effects of urbanization than others (e.g., GIPPET et al. 2017). This pattern emphasises the importance of investigating a wide variety of different organisms for the possible effects of urbanization. The effects of urbanization on terrestrial habitats, for example, have mainly been investigated in birds, butterflies, bees, and other insects (NIELSEN et al. 2014; BENINDE et al. 2015; MERCKX \& VAN DYCK 2019; FRANZÉN et al. 2020; KUUSSAARI et al. 2021). Likewise, the most common study objects of comparable aquatic studies on urbanization are aquatic insects (JEANMOUGIN et al. 2014; TÜZÜN et al. 2015; BLICHARSKA et al. 2017; HEINO et al. 2017), macroinvertebrates in general (Hill et al. 2015; NOBLE \& HASSALl 2015; TALAGA et al. 2017; THORNHILl et al. 2017), fish (CÔTE et al. 2021) or Amphibia (e.g., HAMER \& MCDONNELL 2008; VignOli et al. 2009; JOHNSON et al. 2013; KONOWALIK et al. 2020). Thus, the responses of many aquatic organism groups to urbanization remain understudied, such as molluscs, zooplankton and other crustaceans, including ostracods.

The research project SPEEDY (SPatial and environmental determinants of Eco-Evolutionary DYnamics: anthropogenic environments as a model) investigated the effects of urbanization in Flanders and Brussels (North Belgium) in a nested design at local and landscape scales, studying a wide variety of organisms. As part of this same project, BRANS et al. (2017) demonstrated that body size in zooplankton communities generally declined with increasing urbanization but observed the opposite for communities dominated by larger species, where also the effects of spatial scales was the largest. MERCKX et al. (2018) showed in a multiple taxa (aquatic and terrestrial) study of SPEEDY that urban communities generally consist of smaller species, but that the general trend towards smaller-sized species is overruled by filtering for larger species when there is positive covariation between size and dispersal, thus demonstrating that the urban heat island effect and habitat fragmentation in cities are associated with contrasting shifts in body size. A second multiple taxa study, resulting from the same SPEEDY project, provided strong support for general negative impacts of urbanization on abundance and species richness within habitat patches (PIANO et al. 2019). HANASHIRO et al. (2019), finally, studied the freshwater bacterioplankton communities from the same SPEEDY project and, using a metacommunity approach, concluded that environmental factors, rather than urbanization, accounted for the variation in bacterioplankton community structure.

As part of the SPEEDY project, we here analyse the effects of urbanization on non-marine ostracod communities. Ostracods are small (ca $1 \mathrm{~mm}$ long), bivalved crustaceans which can abound in the benthos and amongst macrophytes in freshwater habitats and which have been used in other studies to correlate their occurrence to specific environmental factors both in living communities (MEZQUITA et al. 1999, 2005; PIERI et al. 2007) and in fossil assemblages (DE DECKKER 1988; HORNE et al. 2012; VAN DER MEEREN et al. 2019). The main environmental drivers of presence/absence of ostracod species thus far reported are cited in the discussion (see below). Because MERCKX et al. (2018) already showed that urbanization has no effect on body size in the studied ostracod communities, we expect that urbanization per se might not have a direct effect on ostracod communities.

Here, we test the hypothesis that environmental factors rather than urbanization influences ostracod community structure. This implies that changes in environmental factors influenced by urbanization, rather than the degree of urbanization itself, have an impact on the ostracod community structure.

\section{Material and methods}

\section{Study area}

We sampled 81 small and shallow pools in Flanders and Brussels Region (Northern Belgium), covering areas with different degrees of urbanization. Localities were selected using Google Earth and permission to collect was requested and obtained from private owners or official instances prior to the sampling 
event. Urbanization was quantified as the percentage built-up cover (BUC) and was assessed through a GIS-based reference map of Flanders, displaying the precise contours of all built-up areas, but excluding roads and parking infrastructure (LARGE SCALE REFERENCE DATABASE 2013). Three categories of urbanization were defined: low urbanized areas $(0-3 \%$ BUC, reference colour green), intermediate urbanized areas (5-10\% BUC, reference colour yellow) and highly urbanized areas (>15\% BUC, reference colour red). Sampling sites were selected using a nested sampling design adapted by the entire SPEEDY consortium (Figure 1). We selected 27 plots, nine plots for each of the three urbanization categories (low, intermediate, high), at a landscape scale $(3 \times 3 \mathrm{~km})$. Within each of these 27 landscape scale plots, three local scale subplots $(200 \times 200 \mathrm{~m})$ were selected, again one for each of the three urbanization categories. Thus, every landscape scale plot contains three local scale subplots. One pool per subplot was selected for sampling, resulting in 81 sampled pools. Within the SPEEDY project the same sampling plots were used to collect a diverse set of aquatic and terrestrial target organisms (MERCKX et al. 2018). Percentage built-up cover was defined more precisely at a later stage by seven spatial scales ( $50 \mathrm{~m}$ to 3,200 $\mathrm{m}$ radii) around each pool, allowing the analyses of the effect of urbanization at even finer scales.

Belgium, and by further reduction northern Belgium (Flanders), covers a relatively small area with a limited number of types of lentic water bodies. Moreover, the fact that these water bodies had to be found within the boundaries of the (sub-)plots again limited the choice. Water bodies were located

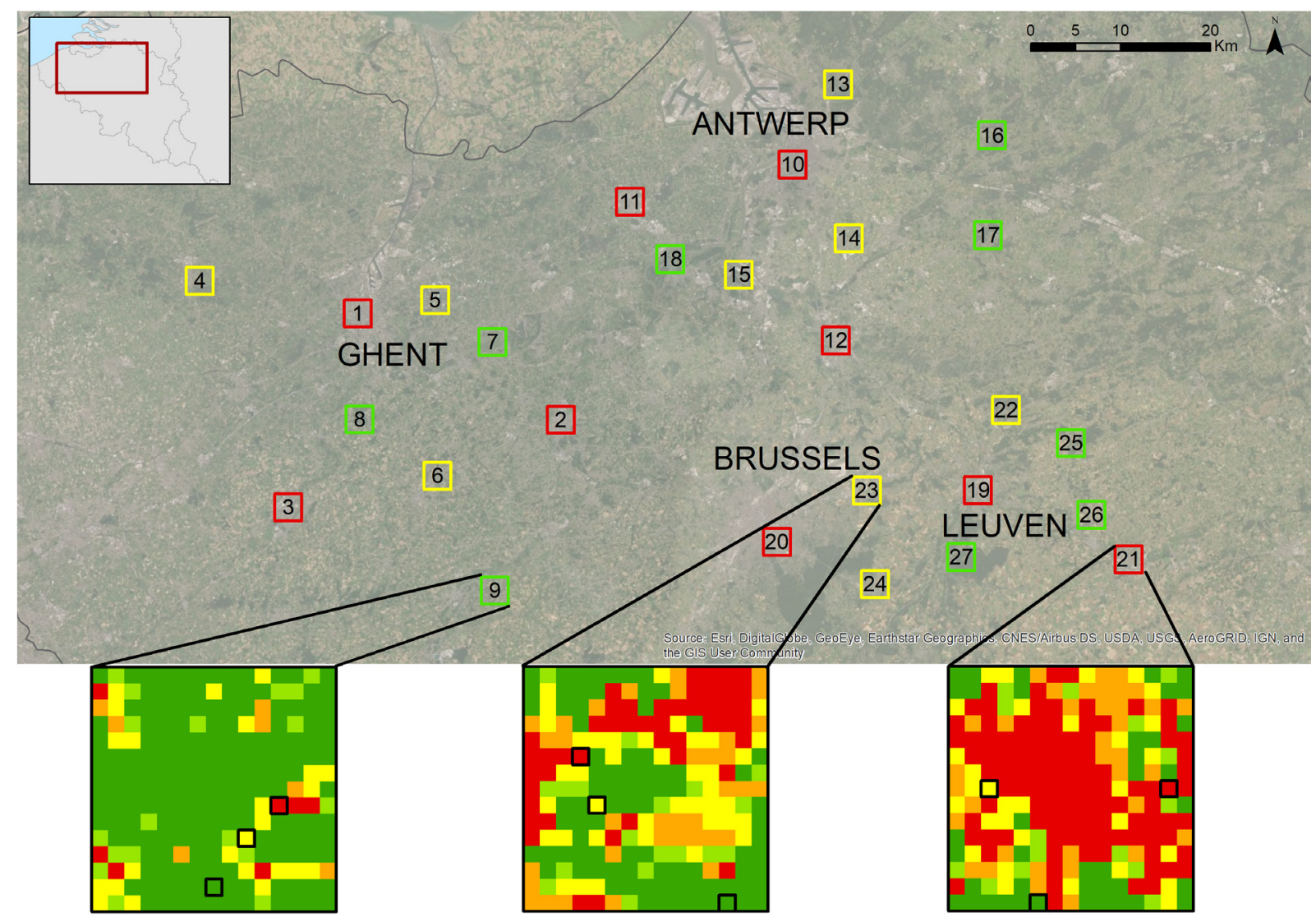

Figure 1 - Map of the study area. The configuration of the landscape-scale sampling plots: nine plots with low urbanization level (0-3\% built-up ratio), nine plots with intermediate urbanization level (5$10 \%$ built-up ratio), and nine plots with a high urbanization level ( $>15 \%$ built-up ratio). Within each of these 27 plots $(3 \times 3 \mathrm{~km}$, landscape-scale), 3 subplots $(200 \times 200 \mathrm{~m}$, local-scale) were selected using the same criteria of built-up ratio, resulting in 81 sampled subplots. 
using Google Earth. These water bodies could be permanent, semi-permanent (drying in very dry summers) and temporary (drying annually); vegetated or not, with or without fish, small-medium-large (see Supplementary Table S1), etc. By the nature of the sampling design, such variability should be randomized. The degree of urbanization in the different (sub-)plots (green, yellow, red) determined the degree of artificial versus natural ponds, concrete versus natural sediments, garden versus natural ponds, etc.

\section{Sampling and sample treatment}

Sampling was carried out in the summer of 2014. Water temperature (WT), pH and electrical conductivity of open water were measured in situ with standard electrodes (WTW LF 340 for conductivity and temperature and WTW pH 340 for $\mathrm{pH}$ measurements) prior to disturbance of the water column. Several quantitative aspects of the ponds (such as estimate surface) were noted. Depth-integrated water samples were taken for detailed analyses of water chemistry and suspended solids in the laboratory and were stored according to standard protocols for transport to the laboratory (see Appendix). Ostracod samples were obtained using a hand net with mesh size of $160 \mu \mathrm{m}$. The hand net was swept in between the vegetation and forcefully right above the surface of the sediment (MARTENS \& HORNE 2016) for a standard period of time (ca 5-10 min) depending on the amount of emerging and submerged macrophytes. Ostracod samples were fixed in $99 \%$ pure ethanol.

To determine total suspended solids (TSS), water (up to $200 \mathrm{ml}$ ) was filtered over a pre-weighed Whatman GF/F filter $(0.7 \mu \mathrm{m})$ that had been dried at $105^{\circ} \mathrm{C}$ for 6 hours. After filtration, the filters were dried and weighted again following the same procedure. The difference in weight divided by the amount of filtered water represents the total suspended solids.

Chemical variables measured in the laboratory included nutrients (nitrite, sum of nitrite and nitrate, orthophosphate, ammonium, silicate), pigments (chlorophyll a (Chl a), chlorophyll b, pheophytin a, pheophytin b (pheo b)), Total Nitrogen (TN), Total Phosphate (TP), Dissolved Organic Carbon (DOC), and salinity. Details of the most relevant results are provided in Electronic Supplementary Material (Supplementary Table S1). Details of full results will be given in the Freshwater Metadata Journal. Because of privacy reasons, owners of most ponds have requested not to publish exact coordinates, but approximate positions are visible in Figure 1.

Quality assurance was an integral part of theses analyses, using in-house reference materials, duplicated measurements and participation in ring tests. Approximately $95 \%$ of the obtained results were regarded as satisfactory when their absolute z-scores (or standard scores) were smaller than 2 (see Appendix). Here, the z-score is calculated by subtracting the average value of a duplicated measurement from the true value of measuring the reference material, divided by the target error.

Sorting of the ostracod samples was performed in the laboratory using a binocular microscope (Leica MZ16). Up to a maximum of 100 ostracods were picked out randomly from each sample using a needle and pipette. Sorted ostracods were stored in a $1.5 \mathrm{~mL}$ microcentrifuge Eppendorf tube in $99 \%$ pure ethanol at $4^{\circ} \mathrm{C}$. Species identification was performed using the key of MEISCH (2000), the taxonomy in MEISCH et al. (2019) and both binocular and light transmission microscopes, the latter after dissection of selected ostracod specimens.

\section{Data analyses}

The ostracod community structure was visualised performing non-metric multidimensional scaling (NMDS), using relative abundance data based on a Bray-Curtis dissimilarity matrix. 
To analyse the effect of urbanization levels on the ostracod community structure we used Permutational Analysis of Variance (PERMANOVA) to test for differences in ostracod communities sampled from pools with different urbanization levels, based on a Bray-Curtis dissimilarity matrix calculated from relative abundance data. To be able to include the 21 pools without any ostracods present, a dummy variable was added to the relative abundance data. The nested study design was considered by constraining permutations for Landscape scale urbanization.

To assess the contribution of individual environmental variables to the observed variability in the ostracod community structure, we performed a distance-based linear modelling (DistLM) with BrayCurtis similarity measure using the stepwise selection procedure and the Akaike Information Criterion (AICc) as decision criterion. To exclude collinear environmental variables, we performed variance inflation factor (VIF) selection by sequentially dropping the environmental variable with the highest VIF from the model, until all VIF values were smaller than 3 (ZUUR et al. 2010). After VIF selection, 16 environmental variables were left (WT, pH, electrical conductivity (EC), suspended solids (TSS), TP, TN, $\mathrm{NH}_{4}^{+}, \mathrm{Si}, \mathrm{NO}_{3}^{-}$, Chl a, salinity, DOC, surface size, BUC for $50 \mathrm{~m}, 200 \mathrm{~m}$ and 3,200 m radius - see Appendix for clarifications) for DistLM analysis. Chl $\mathrm{b}$ and pheo $\mathrm{b}$ were removed because of the high number of measurements below the measuring threshold. When necessary, environmental variables were log-transformed to stabilize the variance and to reduce outliers. To visualize the DistLM results, we carried out a Distance-based redundancy analysis (dbRDA).

Next to DistLM analysis, we also performed a PERMANOVA to investigate marginal effects of temperate and $\mathrm{pH}$ on the ostracod community structure. Temperature could be of great importance because of the urban heat island effect in the highly urbanized plots. $\mathrm{pH}$ has a great influence on the ostracod valve calcification each time after moulting and could therefore have an important influence on the ostracod community structure (MARTENS \& HORNE 2009).

NMDS was performed in R using the vegan and ggplot2 packages (OKSANEN et al. 2015; WICKHAM 2016), All PERMANOVA were performed in $\mathrm{R}$ version 3.6.1 using the adonis 2 function of the vegan package (OKSANEN et al. 2015). DistLM and dbRDA were performed in PRIMER 6 with PERMANOVA add-on (ANDERSON et al. 2008). We selected colours (bluish green, yellow and vermillion) from a colourblind-friendly palette to use in the figures (OKABE \& ITO 2002).

\section{Results}

\section{Ostracod diversity and community structure versus urbanization}

Non-marine ostracods were present in 60 out of 81 sampling locations. Seventeen ostracod species were recorded (Table 1), of which Cypria ophtalmica and Cypridopsis vidua were most frequent and most abundant. Only five species occurred in more than two pools. Three species were found in pools of all three local scale urbanization categories (Figure 2). Two species were unique for pools with high local scale urbanization. Five species occurred only in pools with intermediate local scale urbanization. Only one species (Fabaeformiscandona breuili) was restricted to pools with low local scale urbanization. Most species show very wide temperature tolerances, according to $\mathrm{MEISCH}$ (2000) for water temperature categories and HoRNE \& MEZQUITA (2008) for air temperature tolerance ranges based on the NODE (Non-marine Ostracod Distribution in Europe) database (HoRNE et al. 1998).

PERMANOVA showed no significant effect of local scale urbanization on the ostracod community structure (pseudo-F $=1.81, P=0.10$, Figure 3 ). 


\section{TABLE 1}

Ostracod species found during the SPEEDY survey, with number of pools, water temperature tolerance indication following MEISCH (2000) and air temperature ranges following HORNE \& MEZQUITA (2008).

\begin{tabular}{|c|c|c|c|c|c|c|}
\hline Species & $\begin{array}{l}\text { Occurrence } \\
\text { in \# pools }\end{array}$ & $\begin{array}{l}\text { Water temperature } \\
\text { tolerance (MEISCH }\end{array}$ & \multicolumn{4}{|c|}{$\begin{array}{l}\text { Air temperature } \\
\text { ranges }\left({ }^{\circ} \mathrm{C}\right) \text { (HORNE } \& \\
\text { MEZQUITA 2008) }\end{array}$} \\
\hline & & & \multicolumn{2}{|c|}{ July } & \multicolumn{2}{|c|}{ January } \\
\hline Cyclocypris ovum (Jurine, 1820) & 3 & thermoeuryplastic & 7 & 26 & -17 & 14 \\
\hline Cypria ophtalmica (Jurine, 1820) & 49 & thermoeuryplastic & 6 & 28 & -8 & 14 \\
\hline Cypria subsalsa Redeke, 1936 & 2 & unknown & \multicolumn{4}{|c|}{ unknown } \\
\hline Candonopsis kingsleii (Brady \& Robertson, 1870) & 4 & thermoeuryplastic & 12 & 28 & -5 & 13 \\
\hline Fabaeformiscandona breuili (Paris, 1920) & 1 & unknown & \multicolumn{4}{|c|}{ unknown } \\
\hline Fabaeformiscandona fabaeformis (Fischer, 1851) & 1 & mesothermophilic & 13 & 25 & -8 & 11 \\
\hline Pseudocandona hartwigi (G.W. Müller, 1900) & 1 & polythermophilic & 15 & 23 & -5 & 5 \\
\hline Ilyocypris inermis Kaufmann, 1900 & 1 & cold stenothermal & \multicolumn{4}{|c|}{ unknown } \\
\hline Notodromas monacha (O.F. Müller, 1776) & 12 & warmstenothermal & 14 & 28 & -10 & 10 \\
\hline Herpetocypris chevreuxi (Sars, 1896) & 2 & thermoeuryplastic & 10 & 33 & -1 & 16 \\
\hline Prionocypris zenkeri (Chyzer \& Toth, 1858) & 1 & oligothermophilic & 14 & 26 & -4 & 6 \\
\hline Cypridopsis vidua (O.F. Müller, 1776) & 35 & thermoeuryplastic & 9 & 28 & -8 & 17 \\
\hline Plesiocypridopsis newtoni (Brady \& Robertson, 1870) & 1 & warmstenothermal & \multicolumn{4}{|c|}{ unknown } \\
\hline Potamocypris arcuata (Sars, 1903) & 2 & unknown & 13 & 28 & -4 & 17 \\
\hline Potamocypris unicaudata Schäfer, 1943 & 1 & polythermophilic & \multicolumn{4}{|c|}{ unknown } \\
\hline Limnocythere inopinata (Baird, 1843) & 2 & polythermophilic & 12 & 30 & -12 & 16 \\
\hline Darwinula stevensoni (Brady \& Robertson, 1870) & 2 & thermoeuryplastic & 12 & 30 & -10 & 14 \\
\hline
\end{tabular}

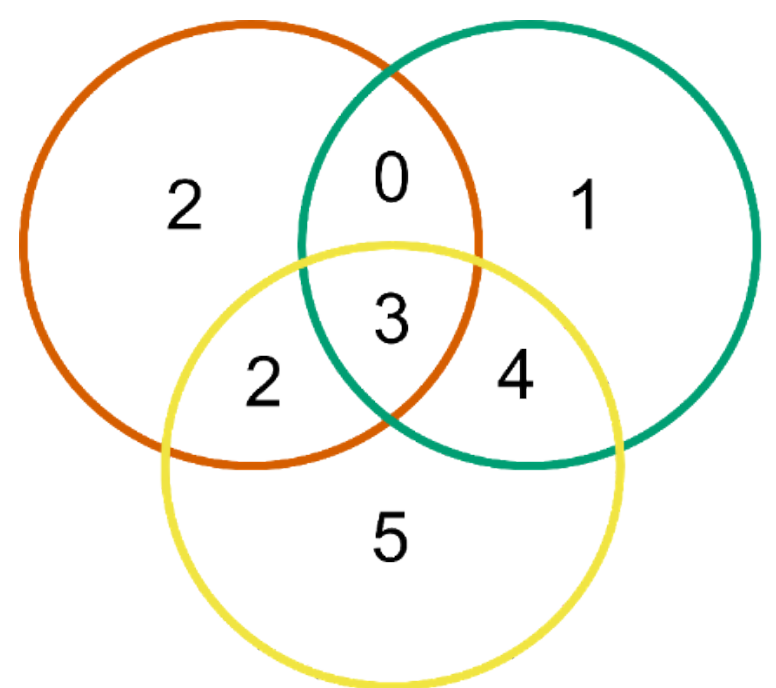

Figure 2 - Exclusive and shared ostracod species for the three urbanization categories on local-scale. There were 21 pools in low (green), 22 pools in intermediate (yellow) and 17 pools in high (red) localscale urbanization areas which contained ostracods. 


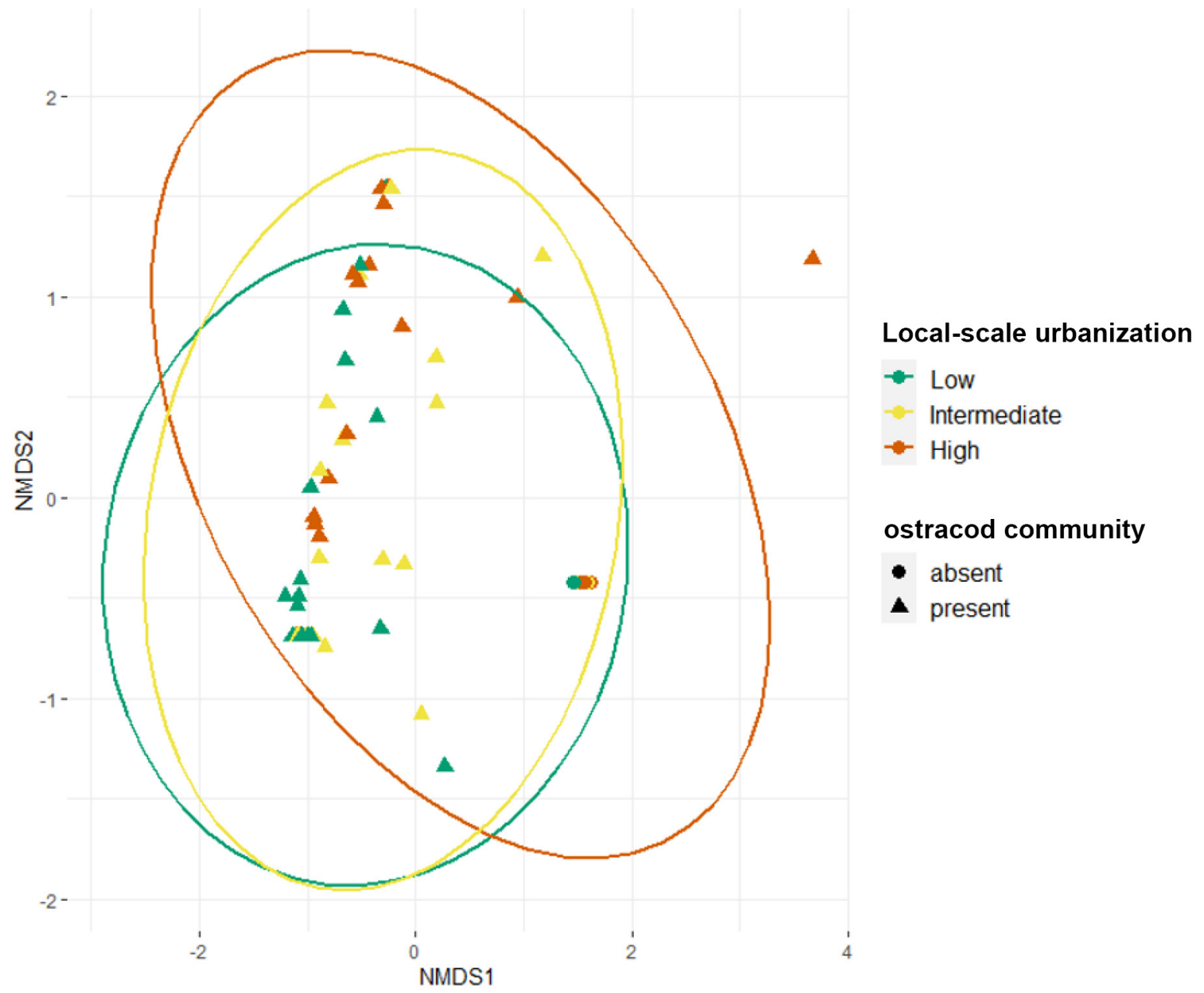

Figure 3 - Non-metric multidimensional scaling analysis of the ostracod community structure across local-scale urbanization. A 95\% data ellipse is depicted by local-scale urbanization. Stress $=0.08$.

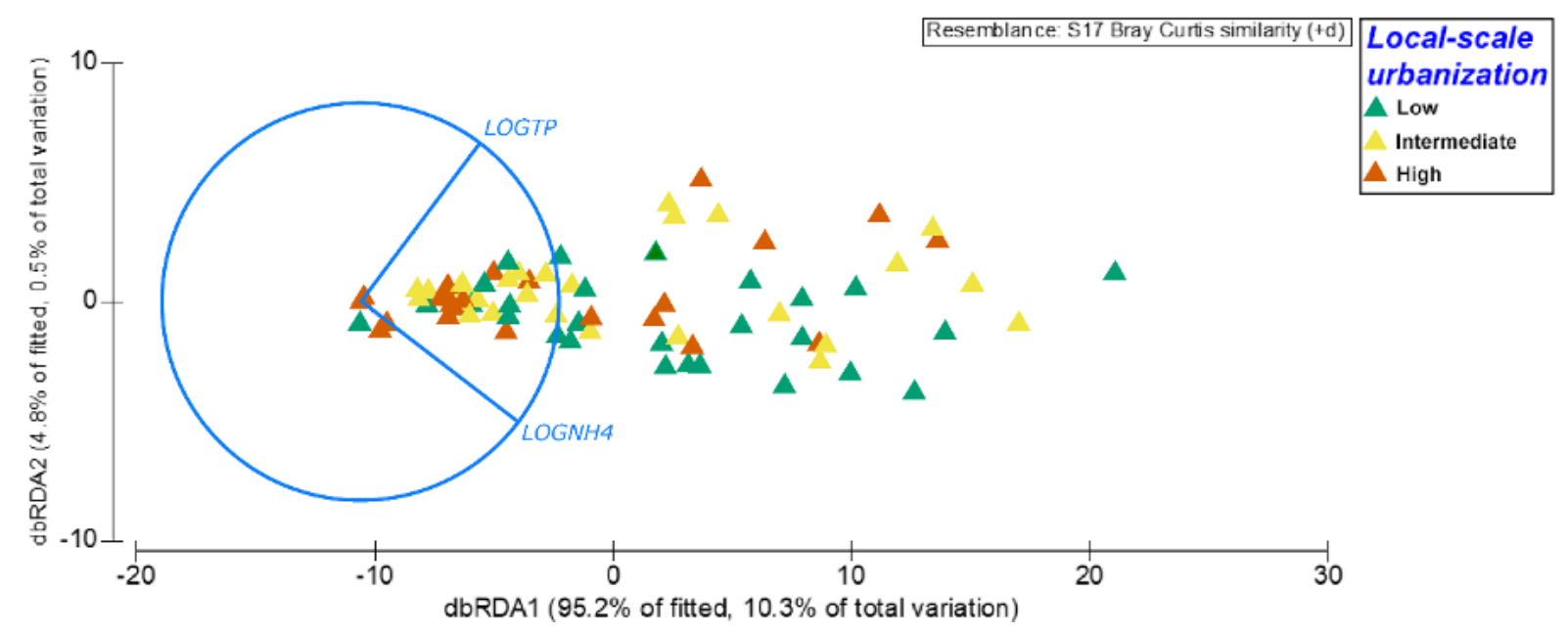

Figure 4 - Distance-based redundancy analysis of the ostracod community structure and environmental variables. Only the environmental variables retained by stepwise selection using distance-based linear modelling are shown. 


\section{Environmental variables and community structure}

DistLM identified the most parsimonious model predicting ostracod communities as the model containing the predictors ammonium $\left(\mathrm{NH}_{4}^{+}\right)$and total phosphorus (TP) (Figure 4). The dbRDA plot shows that ammonium and total phosphorus structures the pools in one cluster containing all 81 locations. $10.3 \%$ of the variation is explained by the model and $95.2 \%$ of the fitted variation is explained by axis 1 . Projection of local scale urbanization shows a (very) slight gradient from highly urbanized areas to intermediate to low urbanized areas following the first axis. Owing to the association of the ammonium and total phosphorus vector with axis 1 , this implies lower total phosphorus and ammonium values in highly urbanized areas. PERMANOVA with marginal tests of temperature and $\mathrm{pH}$ revealed no significant effect on the ostracod community structure (temperature, pseudo- $\mathrm{F}=2.27, P=0.1 ; \mathrm{pH}$, pseudo- $\mathrm{F}=1.78, P=0.16$ ).

\section{Discussion}

\section{Ostracod diversity and community structure}

Seventeen ostracod species were found in 60 pools in the studied area. This is a relatively low number. Comparable surveys have yielded much higher species diversities: 54 species in 48 lentic and lotic localities in the Upper Parana River floodplain (HIGUTI et al. 2010); 47 ostracod species from 33 European lakes (VIEHBERG 2006), 29 species from 36 Canadian lakes (BUNBURY \& GAJEWSKI 2005), 30 species from 100 lakes in Tibet (MiSCHKE et al. 2007) and 47 species from 106 samples in Western Mongolia, including lakes, springs, streams and pools (VAN DER MEEREN et al. 2010). There can be several reasons for this low specific ostracod diversity. Firstly, because the type of sampled habitat was almost invariably shallow pools with small surface area and with comparable morphologies. Individual lakes often have higher alpha biodiversity levels. Nevertheless, several studies have shown that pool systems have higher beta diversities than lakes with comparable total surface area (e.g., DAVIES et al. 2008). This does not seem to be the case here. In addition, the present survey was also carried out in a rather small geographic region, with the pools at the extreme ends of the east-west gradient being only ca $100 \mathrm{~km}$ apart. The study by HIGUTI et al. (2010) covered a comparable area, but this took place in a tropical setting, where diversity is expected to be higher, and also covered a wider variety of habitats and substrates, similar to VAN DER MEEREN et al. (2010). The present study in a small part of Western Europe shows a rather depauperate ostracod fauna in pools.

\section{Effects of urbanization on ostracod community structure}

There is a fast-growing interest in the potential positive (as a haven for threatened species) as well as negative (as a haven for invasive species) impacts of pools on regional aquatic biodiversity (HASSALL \& ANDERSON 2015; HoltMANN et al. 2018, 2019a, 2019b; SinClair et al. 2020; MELAND et al. 2020; PERRON \& PICK 2020a, 2020b and others). In addition, pools are also stepping stones in landscapes facilitating dispersal of aquatic organisms. Still, pools remain relatively under-studied, and research dealing with effects of urbanization on aquatic environments have mostly focussed on larger riverine systems (e.g., CALDERON et al. 2014). In addition, the results of the few existing studies on the effects of urbanization on aquatic pool communities are to some extent contradictory. HILL et al. (2017), working on hundreds of pools in the UK, found that in urban environments, pools show high taxonomic (alpha) richness and form a significant contribution to regional faunal diversity. But JEANMOUGIN et al. (2014) reported that fine scale urbanization, as determined by density of buildings around a pool, decreased alpha diversity in dragonflies. NoBle \& HASSALl (2015) found that macroinvertebrate and plant biodiversity in urban pools in northern England were substantially lower than what would be expected based on pristine reference sites. Contrary to these findings, our results show no significant effect of urbanization on the structure (and on alpha diversity) of ostracod communities. Part of this discrepancy can be related to the way in which the degree of urbanization was determined in the different studies. 
In the present research project SPEEDY, urbanization was determined as percentage built-up cover (BUC) surface GIS analyses. Such an approach does not necessarily take into account the distance of the individual structures to the pools, which generally have very small catchment areas and are thus mostly influenced by close surroundings (HILL et al. 2015). However, other studies found that land cover and land use at considerable distances could still influence pool biodiversity (250 $\mathrm{m}$ in NOBLE \& HASSALL 2015), especially for forested area (up to $400 \mathrm{~m}$ in DECLERCK et al. 2006).

\section{Environmental variables and community structure}

Several local environmental factors can affect the occurrence and abundance of ostracod species and therefore also the structure of the ostracod communities at various spatial scales. Examples of such environmental variables include water chemistry and temperature (MEZQUITA et al. 2005; KÜLKÖYLÜOĞLU et al. 2018), dissolved oxygen, pH and salinity (VAN DER MEEREN et al. 2010; IGLIKOWSKA \& NAMIOTKO 2012; RUIZ et al. 2013; CASTILLO-ESCRIVA et al. 2016; RUMES et al. 2016), pool morphometry and hydro-regime (VANSCHOENWINKEL et al. 2009; PEREIRA et al. 2017), vegetation and substrate including different macrophytes (KISS 2007; HIGUTI et al. 2010), eutrophication (MEZQUITA et al. 1999; POQUET et al. 2008), altitude and water chemistry (POQUET \& MESQUITA-JOANES 2011) and biotic interactions such as predation (MAGNUSSON \& WILLIAMS 2009), to give a few examples.

In general, temperature and $\mathrm{pH}$ are often identified as important significant factors driving non-marine ostracod communities. However, a PERMANOVA test found no significant effect of these factors in the present survey. Possibly, the study area was too uniform with regard to geology, altitude and climate to allow for significant differences. But HiLL et al. (2015), working on urban pools in Loughborough (UK), found quite different environmental conditions, even between pools in close proximity. Especially the fact that temperature was apparently not a relevant factor across three levels of urbanization is surprising, as cities are considered to be urban heat islands. Within the same SPEEDY project, MERCKX et al. (2018) illustrated the reality of this urban heat island effect, while a community shift towards thermophilic species in carabid beetles as a consequence of urbanization was demonstrated by PIANO et al. (2019). However, an analysis of the existing literature (MEISCH 2000; HORNE 2007) on temperature preferences/ tolerances of the ostracod species found in the present survey shows that the majority have relatively wide temperature tolerances (Table 1), so that the relatively minor temperature differences between the urbanization levels might not have caused a shift in the structure of the ostracod communities.

A dbRDA analysis of the present ostracod data showed that ammonium $\left(\mathrm{NH}_{4}^{+}\right)$and total phosphorus (TP) were the main factors predicting ostracod communities (Figure 4). Here, pools in urbanized (built-up) areas were compared to non- or less urbanized areas. Given the nature of land-use in northern Belgium, the non-urbanized areas are generally agricultural areas (crops, cattle). Although such surroundings have different effects than the urbanized heat islands that cities are, they should also be considered anthropized areas, where fertilisation practises would contribute effectively to exactly these two variables of water chemistry (TP and $\mathrm{NH}_{4}^{+}$). ROSSETTI et al. (2020) described that lowland springs in the Po river plain (Italy) had unusually low ostracod diversity, with mostly common and temperature-tolerant species. Springs are often ecotones, in which a mixture of surface and subterranean faunas can lead to high alpha (individual springs) and gamma (regional) diversity of more specialised taxa. ROSSETTI et al. (2020) found that their springs had high nitrate levels, which they also interpret as a result of agricultural practices. SHEN et al. (2021) also identified TP and $\mathrm{NH}_{4}{ }^{+}$besides $\mathrm{TN}$ and Chromium as the main factors driving zooplankton species diversity in urbanized river wetlands. In their study, zooplankton species richness was negatively affected by the concentration of these nutrients and of heavy metals, but also by urbanization (estimated as distance to the nearest city). The present research project SPEEDY compared urbanized areas with differently anthropized surroundings, which might explain the lack of significant differences in ostracod community structure. 
Other potential drivers of pool biodiversity for other faunal groups are pool size (BLICHARSKA et al. 2017 on insects in Stockholm pools); submerged macrophytes (HILl et al. 2017 on hundreds of UK pools) and connectivity (NOBLE \& HASSALL 2015 on pools in Bradford, UK). None of these factors showed up as relevant in the present analyses of ostracod communities.

\section{Conclusions}

The survey of non-marine ostracod communities in 81 SPEEDY pools in northern Belgium showed a rather impoverished fauna of only 17 species. No direct effect of urbanization on these ostracod communities was detected. Only some local factors of water chemistry, chiefly nutrients related to eutrophication, appeared to have an effect on community structure, namely TP and $\mathrm{NH}_{4}{ }^{+}$. These factors are most likely resulting from the fact that pools situated in un- or less urbanized plots were predominantly in agricultural areas. The urban heat island effect of urbanized plots in cities could not be detected in the ostracod communities, which consisted mainly of species with wide temperature tolerances.

\section{Acknowledgements}

This research is part of the SPEEDY-project (SPatial and environmental determinants of Eco-Evolutionary DYnamics: anthropogenic environments as a model), funded by the Interuniversity Attraction Poles program of the Belgian Science Policy Office BELSPO (IAP-grant P7/04) and coordinated by Prof. L. De Meester (University of Leuven, Belgium, and Leibniz-Institute of Freshwater Ecology and Inland Fisheries (IGB), Berlin, Germany). We thank all partners in the SPEEDY consortium for their help in the overall design and running of the SPEEDY program on quantifying population and community responses to urbanization, especially Hans Matheve from Ghent University (Belgium) for setting up the urbanization-based sampling plots and for creating Figure 1 for the present paper. The State University of Maringá (UEM, Maringá) and the Royal Belgian Institute of natural Sciences (RBINS, Brussels) have a bilateral Memorandum of Understanding regarding collaborative Scientific Research.

\section{References}

AlBERTI M. (2015). Eco-evolutionary dynamics in an urbanizing planet. Trends in Ecology \& Evolution 30 (2): 114-126. https://doi.org/10.1016/j.tree.2014.11.007

Alberti M., Correa C., Marzluff J.M., Hendry A.P., Palkovacs E.P., Gotanda K.M., Hunt V.M., APGAR T.M. \& ZHOU Y. (2017). Global urban signatures of phenotypic change in animal and plant populations. Proceedings of the National Academy of Sciences 114 (34): 8951-8956.

https://doi.org/10.1073/pnas.1606034114

ALLAN J.D. (2004). Landscapes and riverscapes: the influence of land use on stream ecosystems. Annual Reviews of Ecology, Evolution and Systematics 35: 257-284.

https://doi.org/10.1146/annurev.ecolsys.35.120202.110122

ANDERSOn M.J., Gorley R.N. \& ClARKe K.R. (2008). PERMANOVA+for PRIMER: Guide to Software and Statistical Methods. PRIMER-E Ltd, Plymouth.

Beninde J., VeITH M. \& HochKIRCH A. (2015). Biodiversity in cities needs space: a meta-analysis of factors determining intra-urban biodiversity variation. Ecology Letters 18 (6): 581-592.

https://doi.org/10.1111/ele.12427

Biggs J., Williams P., Whitfield M., Nicolet P. \& WeATHERby A. (2005). 15 years of pool assessment in Britain: results and lessons learned from the work of Pool Conservation. Aquatic Conservation: Marine and Freshwater Ecosystems 15(6): 693-714. https://doi.org/10.1002/aqc.745 
Blicharska M., Andersson J., Bergsten J., Bjelke U., Hilding-Rydevik T., Thomsson M., ÖSTH J. \& JOHANSSON F. (2017). Is there a relationship between socio-economic factors and biodiversity in urban pools? A study in the city of Stockholm. Urban Ecosystems 20 (6): 1209-1220.

https://doi.org/10.1007/s11252-017-0673-2

Boix D., Biggs J., Céréghino R., Hull A.P., KalettKa T. \& Oertli B. (2012). Pool research and management in Europe: "Small is Beautiful". Hydrobiologia 689 (1): 1-9.

https://doi.org/10.1007/s10750-012-1015-2

BRADLey C.A. \& Altizer S. (2007). Urbanization and the ecology of wildlife diseases. Trends in Ecology \& Evolution 22 (2): 95-102. https://doi.org/10.1016/j.tree.2006.11.001

Brans K I., Govaert L., Engelen J.M., Gianuca A.T., Souffreau C. \& De Meester L. (2017). Eco-evolutionary dynamics in urbanized landscapes: evolution, species sorting and the change in zooplankton body size along urbanization gradients. Philosophical Transactions of the Royal Society B: Biological Sciences 372 (1712): 20160030. https://doi.org/10.1098/rstb.2016.0030

BUNBURY J. \& GAJEWSKI K. (2005). Quantitative analysis of freshwater ostracode assemblages in southwestern Yukon Territory, Canada. Hydrobiologia 545: 117-128.

https://doi.org/10.1007/s10750-005-2746-0

Calderon M.R., GonzÁlez P., Moglia M., Gonzáles S.O. \& Jofré M. (2014). Use of multiple indicators to assess the environmental quality of urbanized aquatic surroundings in San Luis, Argentina. Environmental monitoring and assessment 186 (7): 4411-4422.

https://doi.org/10.1007/s10661-014-3707-8

Castillo-Escrivà A., Valls L., Rochera C., Camacho A. \& Mesquita-Joanes F. (2016). Spatial and environmental analysis of an ostracod metacommunity from endorheic lakes. Aquatic Sciences 78 (4): 707-716. https://doi.org/10.1007/s00027-015-0462-z

CÉRÉGHino R., Biggs J., OeRTLi B. \& DeClerCK S. (2008). The ecology of European pools: defining the characteristics of a neglected freshwater habitat. Hydrobiologia 597: 1-6.

https://doi.org/10.1007/s10750-007-9225-8

Côte J., Morisseau O., Pilisi C., Veyssière C., Perrault A., Jezequel C., Loot G., Blanchet S., JEAN S. \& JACQUIN L. (2021). Urbanization and eutrophication as drivers of morphological and physiological divergence among riverine fish populations. Freshwater Biology 66 (4): 669-682. https://doi.org/10.1111/fwb.13669

Davies B., Biggs J., Williams P., Whitfield M., Nicolet P., Sear D., Bray S., Maund S. (2008). Comparative biodiversity of aquatic habitats in the European agricultural landscape. Agriculture, Ecosystems \& Environment 125 (1-4): 1-8. https://doi.org/10.1016/j.agee.2007.10.006

Declerck S. , De Bie T., Ercken D., Hampel H., Schrijvers S., Van Wichelen J., Gillard V., Mandiki R., Losson B., Bauwens D., Keijers S., Vyverman W., Goddeeris B., De Meester L., BRENDONCK L. \& MARTENS K. (2006). Ecological characteristics of small farm land pools: associations with land-use practices at multiple spatial scales. Biological Conservation 131: 523-532.

https://doi.org/10.1016/j.biocon.2006.02.024

De DeCKKeR P. (1988). An account of the techniques using ostracodes in palaeolimnology in Australia. Palaeogeography, Palaeoclimatology, Palaeoecology 62: 463-475.

https://doi.org/10.1016/0031-0182(88)90067-3

DONinue C.M. \& LAMBERT M.R. (2015). Adaptive evolution in urban ecosystems. Ambio 44 (3): 194 203. https://doi.org/10.1007/s13280-014-0547-2 
Dudgeon D., Arthington A.H., Gessner M.O., Kawabata Z.I., Knowler D.J., LévêQue C., Naiman R.J., PrieuR-Richard A.-H., Soto D., Stiassny M.L. \& Sullivan C. A. (2006). Freshwater biodiversity: importance, threats, status and conservation challenges. Biological reviews 81 (2): 163182. https://doi.org/10.1017/S1464793105006950

Ellis E.C., GoldewiJK K.K., Siebert S., Lightman D. \& RamanKutTy N. (2010). Anthropogenic transformation of the biomes, 1700 to 2000. Global Ecology and Biogeography 19: 589-606. https://doi.org/10.1111/j.1466-8238.2010.00540.x

Franzén M., Betzholtz P.E., Pettersson L.B. \& Forsman A. (2020). Urban moth communities suggest that life in the city favours thermophilic multi-dimensional generalists. Proceedings of the Royal Society B 287 (1928): 20193014. https://doi.org/10.1098/rspb.2019.3014

Gippet J.M., Mondy N., Diallo-Dudek J., Bellec A., Dumet A., Mistler L. \& Kaufmann B. (2017). I'm not like everybody else: urbanization factors shaping spatial distribution of native and invasive ants are species-specific. Urban Ecosystems 20 (1): 157-169.

https://doi.org/10.1007/s11252-016-0576-7

HAMER A.J. \& MCDONNELL M.J. (2008). Amphibian ecology and conservation in the urbanising world: a review. Biological conservation 141 (10): 2432-2449. https://doi.org/10.1016/j.biocon.2008.07.020

Hanashiro F.T.T., Mukherjee S., Souffreau C., Engelen J., Brans K.I., Busschaert P. \& De MEester L. (2019). Freshwater Bacterioplankton Metacommunity Structure Along Urbanization Gradients in Belgium. Frontiers in microbiology 10: 743. https://doi.org/10.3389/fmicb.2019.00743

HASSALl C. (2014). The ecology and biodiversity of urban pools. Wiley Interdisciplinary Reviews: Water 1 (2): 187-206. https://doi.org/10.1002/wat2.1014

HASSALl C. \& ANDERSON S. (2015). Stormwater pools can contain comparable biodiversity to unmanaged wetlands in urban areas. Hydrobiologia 745 (1): 137-149.

https://doi.org/10.1007/s10750-014-2100-5

Heino J., Bini L.M., Andersson J., Bergsten J., Bjelke U. \& Johansson F. (2017). Unravelling the correlates of species richness and ecological uniqueness in a metacommunity of urban pool insects. Ecological indicators 73: 422-431. https://doi.org/10.1016/j.ecolind.2016.10.006

Higuti J., Declerck S.A.J., Lansac-TôHa F.A., Machado Velho L.F. \& Martens K. (2010). Variation in ostracod (Crustacea, Ostracoda) communities in the alluvial valley of the upper Paraná River (Brazil) in relation to substrate. Hydrobiologia 644: 261-278.

https://doi.org/10.1007/s10750-010-0122-1

HiLl M.J., MATHERS K.L. \& WoOD P.J. (2015). The aquatic macroinvertebrate biodiversity of urban pools in a medium-sized European town (Loughborough, UK). Hydrobiologia 760 (1): 225-238. https://doi.org/10.1007/s10750-015-2328-8

Hill M.J., Biggs J., Thornhill I., Briers R.A., Gledhill D.G., White J.C., WoOD P.J. \& Hassall C. (2017). Urban pools as an aquatic biodiversity resource in modified landscapes. Global Change Biology 23 (3): 986-999. https://doi.org/10.1111/gcb.13401

Holtmann L., Juchem M., BrÜGgeshemke J., MöHlmeyer A. \& FARTMann T. (2018). Stormwater pools promote dragonfly (Odonata) species richness and density in urban areas. Ecological Engineering 118: 1-11. https://doi.org/10.1016/j.ecoleng.2017.12.028

Holtmann L., Kerler K., Wolfgart L., Schmidt C. \& FArTMAnn T. (2019a). Habitat heterogeneity determines plant species richness in urban stormwater pools. Ecological Engineering 138: 434-443. https://doi.org/10.1016/j.ecoleng.2019.07.035 
Holtmann L., BrÜgGeshemke J., Juchem M. \& FARTMAnN T. (2019b). Odonate assemblages of urban stormwater pools: the conservation value depends on pool type. Journal of Insect Conservation 23 (1): 123-132. https://doi.org/10.1007/s10841-018-00121-x

HoRNE D.J. (2007). A mutual temperature range method for Quaternary paleoclimatic analysis using European nonmarine Ostracoda. Quaternary Science Reviews 26 1398-1415.

https://doi.org/10.1016/j.quascirev.2007.03.006

Horne D.J. \& MezQuiTA F. (2008). Palaeoclimatic applications of large databases: developing and testing methods of palaeotemperature reconstruction using nonmarine ostracods. Senckenbergiana lethaea 88: 93-112. https://doi.org/10.1007/bf03043981

Horne D.J., BALTANÁS A. \& PARIS G. (1998): Geographical distriburlon of reproductive modes in living non-marine ostracods. In: MARTENS K. (ed.) Sex and Parthenogenesis: Evolutionary Ecology of Reproductive Modes in Non-Marine Ostracods: 77-99. Backhuys, Leiden, the Netherlands.

Horne D.J., Holmes J.A, Rodriguez-LAZARo J. \& Viehberg F.A. (2012). Ostracoda as Proxies for Quaternary Climate Change: Overview and Future Prospects. Developments in Quaternary Sciences 17: 305-315. https://doi.org/10.1016/B978-0-444-53636-5.00018-4

IGLIKOWSKA A. \& NAMiOTKO T. (2012). The impact of environmental factors on diversity of Ostracoda in freshwater habitats of subarctic and temperate Europe. Annales Zoologici Fennici 49 (4): 193-218. https://doi.org/10.5735/086.049.0401

JeAnMougin M., LePrieur F., LoÏs G. \& Clergeau P. (2014). Fine-scale urbanization affects Odonata species diversity in pools of a megacity (Paris, France). Acta Oecologica 59: 26-34.

https://doi.org/10.1016/j.actao.2014.05.008

Johnson P.T., Hoverman J.T., MCKenZiE V.J., Blaustein A.R. \& Richgels K.L. (2013). Urbanization and wetland communities: applying metacommunity theory to understand the local and landscape effects. Journal of Applied Ecology 50 (1): 34-42. https://doi.org/10.1111/1365-2664.12022

Kiss A. (2007). Factors affecting spatial and temporal distribution of Ostracoda assemblages in different macrophyte habitats of a shallow lake (Lake Fehér, Hungary). Hydrobiologia 585 (1): 89-98. https://doi.org/10.1007/s10750-007-0631-8

Konowalik A., NajBar A., Konowalik K., Dylewski Ł., Frydlewicz M., Kisiel P., STARZecka A., ZALESNAS A. \& KolENDA K. (2020). Amphibians in an urban environment: a case study from a central European city (Wrocław, Poland). Urban Ecosystems 23 (2): 235-243.

https://doi.org/10.1007/s11252-019-00912-3

KÜlKöYlÜOĞlu O., YavuZATMACA M., AKdemir D., ÇElen E. \& DAlKiran N. (2018). Ecological classification of the freshwater Ostracoda (Crustacea) based on physicochemical properties of waters and habitat preferences. Annales de Limnologie-International Journal of Limnology 54 (26): 1-11. https://doi.org/10.1051/limn/2018017

Kuussaari M., Toivonen M., Heliölä J., PÖyry J., Mellado J., Ekroos J., Hyyryläinen V., VÄHÄ-PIIKKIÖ I. \& TIAINEN J. (2021). Butterfly species' responses to urbanization: differing effects of human population density and built-up area. Urban Ecosystems 24 (3): 515-527.

https://doi.org/10.1007/s11252-020-01055-6

LAMBERT M.R. \& DONinUE C.M. (2020). Urban biodiversity management using evolutionary tools. Nature Ecology \& Evolution 4: 903-910. https://doi.org/10.1038/s41559-020-1193-7

LARge ScAle Reference DAtABASE. (2013). Available from https://overheid.vlaanderen.be/en/ producten-diensten/large-scale-reference-database-lrd [accessed 25 November 2021]. 
COURS M. et al., Water chemistry influences ostracod community structure

MAGNuSson A.K. \& WiLliams D.D. (2009). Top-down control by insect predators in an intermittent pool - a field experiment. Annales de Limnologie - International Journal of Limnology 45 (3): 131-143. https://doi.org/10.1051/limn/2009017

MARTENS K. \& Horne D.J. (2009). Ostracoda. In : LiKens G. (ed.) Encyclopedia of Inland Waters 2 : 405-414. Elsevier, Oxford. https://doi.org/10.1016/B978-012370626-3.00184-8

MARTENS K. \& HoRNE D.J. (2016). Collecting and processing living non-marine ostracods. Journal of Crustacean Biology 36 (6): 849-854. https://doi.org/10.1163/1937240X-00002488

MCKINNEY M.L. (2008). Effects of urbanization on species richness: a review of plants and animals. Urban Ecosystems 11 (2): 161-176. https://doi.org/10.1007/s11252-007-0045-4

MeineKe E.K., Dunn R.R., SEXTON J.O \& Frank S.D. (2013). Urban warming drives insect pest abundance on street trees. PLoS ONE 8 (3): e59687. https://doi.org/10.1371/journal.pone.0059687

MeISCH C. (2000). Freshwater Ostracoda of Western and Central Europe. Süsswasserfauna von Mitteleuropa, 8/3: 1-522. Spektrum Akademischer Verlag, Gustav Fischer.

Meisch C., Smith R. \& MARTEns K. (2019). A subjective global checklist of the Recent non-marine Ostracoda (Crustacea). European Journal of Taxonomy 492: 1-135.

https://doi.org/10.5852/ejt.2019.492

Meland S., Sun Z., Sokolova E., Rauch S. \& BritTain J.E. (2020). A comparative study of macroinvertebrate biodiversity in highway stormwater pools and natural pools. Science of the Total Environment 740: 140029. https://doi.org/10.1016/j.scitotenv.2020.140029

Merckx T., Souffreau C., Kaiser A., BaArdsen L.F., Backeljau T., Bonte D., Brans K.I., Cours M., Dahirel M., Debortoli N., De Wolf K., Engelen J.M.T., Fontaneto D., Gianuca A.T., Govaert L., Hendrickx F., Higuti J., Lens L., Martens K., Matheve H., Matthysen E., Piano E., SABlon R., SchÖn I., VAN Doninck K., De MEester L. \& VAN Dyck H. (2018). Body size shifts in aquatic and terrestrial urban communities. Nature 558: 113-116.

https://doi.org/10.1038/s41586-018-0140-0

MERCKX T. \& VAN DYCK H. (2019). Urbanization-driven homogenization is more pronounced and happens at wider spatial scales in nocturnal and mobile flying insects. Global Ecology and Biogeography 28 (10): 1440-1455. https://doi.org/10.1111/geb.12969

MEZquita F., TAPIA G. \& RoCA J.R. (1999). Ostracoda from springs on the eastern Iberian Peninsula: ecology, biogeography and palaeolimnological implications. Palaeogeography, Palaeoclimatology, Palaeoecology 148 (1-3): 65-85. https://doi.org/10.1016/S0031-0182(98)00176-X

MeZquita F., Roca J.R., ReEd J.M. \& WANSARD G. (2005). Quantifying species-environment relationships in non-marine Ostracoda for ecological and palaeoecological studies: examples using Iberian data. Palaeogeography, Palaeoclimatology, Palaeoecology 225 (1-4): 93-117.

https://doi.org/10.1016/j.palaeo.2004.02.052

MischKe S., Herzschun U., Massmann G. \& ZhANG C. (2007). An ostracod-conductivity transfer function for Tibetan lakes. Journal of Paleolimnology 38: 509-524.

https://doi.org/10.1007/s10933-006-9087-5

Nielsen A.B., Van Den Bosch M., Maruthaveeran S. \& Van den Bosch C.K. (2014). Species richness in urban parks and its drivers: a review of empirical evidence. Urban ecosystems 17 (1): 305327. https://doi.org/10.1007/s11252-013-0316-1

NoBle A. \& HASSALl C. (2015). Poor ecological quality of urban pools in northern England: causes and consequences. Urban Ecosystems 18 (2): 649-662. https://doi.org/10.1007/s11252-014-0422-8 
OERTLI B. \& PARRIS K.M. (2019). Toward management of urban pools for freshwater biodiversity. Ecosphere 10 (7): e02810. https://doi.org/10.1002/ecs2.2810

OKABE M. \& ITO K. (2002). Color Universal Design (CUD) - How to make figures and presentations that are friendly to colorblind people. Available from https://jfly.uni-koeln.de/color/ [accessed 24 November 2021].

OKE T.R. (1982). The energetic basis of the urban heat island. Quarterly Journal of the Royal Meteorological Society 108 (455): 1-24. https://doi.org/10.1002/qj.49710845502

Oksanen J., Blanchet F.G., Friendly M., Kindt R., Legendre P., McGlinn D., Minchin P.R., O'Hara R.B., Simpson G.L., Solymos P., Henry M., Stevens H., Szoecs E. \& Wagner H. (2015). Vegan community ecology package: ordination methods, diversity analysis and other functions for community and vegetation ecologists. Available from https:/www.worldagroforestry.org/publication/ vegan-community-ecology-package-ordination-methods-diversity-analysis-and-other [accessed 24 November 2021].

Pereira L.C., Lansac-TôHa F.A., Martens K. \& Higuti J. (2017). Biodiversity of ostracod communities (Crustacea, Ostracoda) in a tropical floodplain. Inland Waters 7: 323-332.

https://doi.org/10.1080/20442041.2017.1329913

PERRON M.A.C. \& PiCK F.R. (2020a). Stormwater pools as habitat for Odonata in urban areas: the importance of obligate wetland plant species. Biodiversity and Conservation 29 (3): 913-931.

https://doi.org/10.1007/s10531-019-01917-2

PERRON M.A.C. \& PICK F.R. (2020b). Water quality effects on dragonfly and damselfly nymph communities: A comparison of urban and natural pools. Environmental Pollution: 114472.

https://doi.org/10.1016/j.envpol.2020.114472

Piano E., Souffreau C., Merckx T., BaArdsen L.F., Backeljau T., Bonte D., Brans K.I., Cours M., Dahirel M., Debortoli N., Decaestecker E., De Wolf K., Engelen J.M.T., Fontaneto D., Gianuca A.T., Govaert L., Hanashiro F.T., Higuti J., Lens L., Martens K., Matheve H., Matthysen E., Pinseel E., Sablon R., Schön I., Stoks R., Van Doninck K., Van Dyck H., Vanormelingen P., Van Wichelen J., Vyverman W., De Meester L. \& HendrickX F. (2019). Urbanization drives cross-taxon declines in abundance and diversity at multiple spatial scales. Global Change Biology 26:1196-1211 (2020). https://doi.org/10.1111/GCB.14934

Pieri V., Caserini C., Gomarasca S., Martens K. \& Rossetti G. (2007). Water quality and diversity of the Recent ostracod fauna in lowland springs from Lombardy (northern Italy). Hydrobiologia 585: 79-87. https://doi.org/10.1007/s10750-007-0630-9

PoQuet J.M. \& MeSQuita-JoAnes F. (2011). Combined effects of local environment and continental biogeography on the distribution of Ostracoda. Freshwater Biology 56 (3): 448-469.

https://doi.org/10.1111/j.1365-2427.2010.02511.x

Poquet J.M., Mezquita F., Rueda J. \& Miracle M.R. (2008). Loss of Ostracoda biodiversity in Western Mediterranean wetlands. Aquatic Conservation: Marine and Freshwater Ecosystems 18 (3): 280-296. https://doi.org/10.1002/aqc.831

Rossetti G., Pieri V., Bolpagni R., Nizzoli D. \& Viaroli P. (2020). Variability in environmental conditions strongly impacts ostracod assemblages of lowland springs in a heavily anthropized area. Water 12: 3276. https://doi.org/10.3390/w12113276

Ruiz F., Abad M., Bodergat A.M., Carbonel P., Rodríguez-LÁzaro J., González-Regalado M.L., Toscano A., GARCiA E.X. \& PRENDA J. (2013). Freshwater ostracods as environmental tracers. International Journal of Environmental Science and Technology 10 (5): 1115-1128.

https://doi.org/10.1007/s13762-013-0249-5 
COURS M. et al., Water chemistry influences ostracod community structure

Rumes B., VAn Der Meeren T., Martens K. \& Verschuren D. (2016). Distribution and community structure of Ostracoda (Crustacea) in shallow waterbodies of southern Kenya. African Journal of Aquatic Science 41 (4): 377-387. https://doi.org/10.2989/16085914.2016.1241174

SHen J., QIN G., YU R., ZhaO Y., YANG J., AN S., RUN L., XIN L. \& WAN Y. (2021). Urbanization has changed the distribution pattern of zooplankton species diversity and the structure of functional groups. Ecological Indicators 120: 106944. https://doi.org/10.1016/j.ecolind.2020.106944

Sinclair J.S., Reisinger A.J., Bean E., Adams C.R., Reisinger L.S. \& IAnNone III B.V. (2020). Stormwater pools: An overlooked but plentiful urban designer ecosystem provides invasive plant habitat in a subtropical region (Florida, USA). Science of the Total Environment 711: 135133.

https://doi.org/10.1016/j.scitotenv.2019.135133

Shochat E., Warren P.S., Faeth S.H., Mcintyre N.E. \& Hope D. (2006). From patterns to emerging processes in mechanistic urban ecology. Trends in Ecology \& Evolution 21 (4): 186-191.

https://doi.org/10.1016/j.tree.2005.11.019

Talaga S., Dézerald O., Carteron A., Leroy C., Carrias J.F., CÉrÉghino R. \& Dejean A. (2017). Urbanization impacts the taxonomic and functional structure of aquatic macroinvertebrate communities in a small Neotropical city. Urban Ecosystems 20 (5): 1001-1009.

https://doi.org/10.1007/s11252-017-0653-6

Thornhill I., BAtTy L., DeAth R.G., FriberG N.R. \& Ledger M.E. (2017). Local and landscape scale determinants of macroinvertebrate assemblages and their conservation value in pools across an urban land-use gradient. Biodiversity and conservation 26 (5): 1065-1086.

https://doi.org/10.1007/s10531-016-1286-4

TÜZÜN N., DEBECKER S., DE BEECK L.O. \& STOKS R. (2015). Urbanization shapes behavioural responses to a pesticide. Aquatic Toxicology 163: 81-88. https://doi.org/10.1016/j.aquatox.2015.04.002

United NATIONS. (2018). Available from https://www.un.org/development/desa/en/news/population/ 2018-revision-of-world-urbanization-prospects.html [accessed 25 November 2021].

VAn der Meeren T., Almendinger J.E., Ito E. \& MArtens K. (2010). The ecology of ostracodes (Ostracoda; Crustacea) in western Mongolia. Hydrobiologia 641: 253-273.

https://doi.org/10.1007/s10750-010-0089-y

VAn der MeERen T., Ito E., LAird K.R., Cumming B.F. \& Verschuren D. (2019). Ecohydrological evolution of Lake Naivasha (central Rift Valley, Kenya) during the past 1650 years, as recorded by ostracod assemblages and stable-isotope geochemistry. Quaternary Science Reviews 223: 105906. https://doi.org/10.1016/j.quascirev.2019.105906

Vanschoenwinkel B., Hulsmans A.N.N., De Roeck E.L.S., De Vries C., Seaman M. \& Brendonck L.U.C. (2009). Community structure in temporary freshwater pools: disentangling the effects of habitat size and hydroregime. Freshwater Biology 54 (7): 1487-1500.

https://doi.org/10.1111/j.1365-2427.2009.02198.x

VIEHBERG F.A. (2006). Freshwater ostracod assemblages and their relationship to environmental variables in waters from northeast Germany. Hydrobiologia 571: 213-224.

https://doi.org/10.1007/s10750-006-0241-x

Vignoli L., Mocaer I., Luiselli L. \& Bologna M.A. (2009). Can a large metropolis sustain complex herpetofauna communities? An analysis of the suitability of green space fragments in Rome. Animal Conservation 12 (5): 456-466. https://doi.org/10.1111/j.1469-1795.2009.00273.x

WiCKHAм H (2016). ggplot2: Elegant Graphics for Data Analysis. Springer-Verlag, New York, 182 pp. 
ZuUR A.F., IENO E.N. \& ElPHICK C.S. (2010). A protocol for data exploration to avoid common statistical problems. Methods in Ecology and Evolution 1 (1): 3-14.

https://doi.org/10.1111/j.2041-210X.2009.00001.x

Manuscript received: 20 July 2021

Manuscript accepted: 25 November 2021

Published on: 3 December 2021

Branch editor: Stuart Halse

Supplementary Table S1: Major characteristics of SPEEDY ponds. 


\section{Appendix}

\section{Details of methods for analysing water chemistry variables}

Water samples were stored in a cold box and processed within $24 \mathrm{~h}$ in the laboratory.

Filtration for nutrient analysis was performed using cellulose acetate membrane filters $(47 \mathrm{~mm}$, porosity $0.2 \mu \mathrm{m})$ and the filtrate collected in PE bottles, samples were stored deep frozen $\left(-20^{\circ} \mathrm{C}\right)$ until analysis. Samples for salinity analysis were not filtered, and stored in amber glass bottles at room temperature until analysis. Samples for pigment analysis were filtered on Whatman GF/C filters, each filter folded and transferred into a cryovial, flash frozen in liquid nitrogen and stored at $-80^{\circ} \mathrm{C}$ until analysis.

Nutrient concentrations were determined with a Skalar auto-analyser system. The concentration of Nitrite $\left(\mathbf{N O}_{2}\right)$ was measured through diazo-coupling with sulfanylamide and naphtylene diamine di-hydrochloric acid and measuring the extinction of the complex at $540 \mathrm{~nm}$. The sum of nitrite and nitrate $\left(\mathbf{N O}_{\mathbf{x}}\right)$ was analysed by reducing the nitrate catalytically over a $\mathrm{Cd}-\mathrm{Cu}$ column followed by the same methodology as for nitrite. Result subtraction was used to determine Nitrate concentrations. Orthophosphate $\left(\mathbf{P O}_{4}{ }^{3-}\right)$ was determined by its reaction with molybdate and ascorbic acid, followed by acidification in the presence of $\mathrm{Sb}$, and measuring the resulting blue complex subsequently at $880 \mathrm{~nm}$ in a spectrometer. For ammonium $\left(\mathbf{N H}_{4}^{+}\right)$, the reaction was conducted in EDTA (ethylene diamine tetraacetate) buffer, with sodium salts of salicylate, nitroprusside and hypochlorite. In alkaline conditions, the formed emerald green was measured spectrophotometrically at $630 \mathrm{~nm}$. To reduce any interference of phosphate, oxalic acid was first added to the samples for analysing Silicate (Si), followed by the addition of molybdate and ascorbic acid. The amount of formed blue compound (molybdene blue) was measured in a spectrometer at $810 \mathrm{~nm}$. Pigments (chlorophyll a (chl a), chlorophyll b (chl b), pheophytin a (pheo a) and pheophytin $b$ (pheo b)) were extracted by adding $90 \%$ acetone (diluted with ultrapure water) and blended with glass pearls in a Bullet Blender with dry ice cooling, followed by centrifugation. The clear supernatant was analysed by UPLC (ultrahigh pressure liquid chromatography) with fluorometric detection (excitation at $430 \mathrm{~nm}$ and detection at $660 \mathrm{~nm}$ ). For measuring total Nitrogen (TN), potassium peroxodisulphate in a borate buffer was added to the samples and then exposed to UV to convert organic nitrogen into inorganic nitrogen. Next, ammonium chloride was added and the mixture was distilled through a gas exchange membrane. Nitrate was converted to nitrite by reducing the nitrate catalytically over a Cd-Cu column followed by the same methodology as for nitrite. Similar to the analyses of TN, also Total Phosphate (TP) was determined by first adding potassium peroxodisulphate in a borate buffer and the mixture then exposed to UV light to convert organic phosphate to orthophosphate followed by the same methodology as for orthophosphate (see above). To remove inorganic carbon for measuring the concentration of Dissolved Organic Carbon (DOC), sulphuric acid was added first, followed by potassium peroxodisulphate in a borate buffer and UV exposure converting organic carbon to $\mathrm{CO}_{2}$. The resulting mixture was distilled through a gas exchange membrane into a colouring reagent. The associated drop in $\mathrm{pH}$ is reflected by a reduced colour intensity, and this is measured in a spectrometer at $550 \mathrm{~nm}$. The concentration of chloride was measured with a Guildline Portasal 8410 Salinometer by comparing the conductivity of a sample to a reference solution. This ratio combined with temperature allows to calculate salinity using Practical Salinity Scale Equations (LEWIS 1980). The salinometer consists of glass cells containing the samples, which are placed in a strictly thermally stabilized environment, and it is equipped with 4 Pt-electrodes coupled to a microprocessor controlled measuring bridge.

\section{References}

LEWIS E. (1980). The practical salinity scale 1978 and its antecedents. IEEE Journal of Oceanic Engineering 5 (1): 3-8. https://doi.org/10.1109/JOE.1980.1145448 